\title{
DEVELOPING MAGIC ROUND TO TEACH INTERROGATIVE SENTENCES
}

\author{
Tri Agustini Solihati \\ English Education Department, Faculty of Education and Teacher Training, \\ Universitas Perjuangan Tasikmalaya, Indonesia \\ E-mail: triagustini@unper.ac.id \\ Lystiana Nurhayat Hakim \\ English Education Department, Faculty of Education and Teacher Training, \\ Universitas Perjuangan Tasikmalaya, Indonesia \\ E-mail: lystiananurhayat@unper.ac.id
}

\begin{abstract}
APA Citation: Solihati, T. A., \& Hakim, L. N. (2019). Developing magic round to teach interrogative sentences. English Review: Journal of English Education, 8(1), 129-138. doi: 10.25134/erjee.v8i1.2030.
\end{abstract}

Received: 22-09-2019

Accepted: 18-10-2019

Published: 01-12-2019

\begin{abstract}
Vocabulary mastery and sentence structure are often considered to be the most challenging things in mastering English. Besides, both teacher and students are often bored on how they are explained and understood. Thus, keeping students' motivation in learning vocabulary and sentence structure needs more effort as it should be more than just teachers' attendance and explanation. Choosing a proper teaching media can be one of the solutions. This research aims to produce Magic Round as one of the choices for teaching interrogative sentences. It was developed through Research and Development (R\&D) by implementing several steps, including preliminary studies, research planning, product design, product validation, product trial, and producing final product. Validity was assessed by both technological and material experts. Those reached $90 \%$ and $92 \%$. The usefulness and feasibility were taken by the user and observer. Those gained $91 \%$ and $91 \%$. In conclusion, this media is quiet appropriate to be used in teaching English interrogative sentences.
\end{abstract}

Keywords: magic round; interrogative sentences; research and development; supplementary teaching media; tenses.

\section{INTRODUCTION}

The objective of teaching English in Indonesia based on the 2006 Standard of Content is that the students can develop their communicative competence, both in oral or written forms, to achieve a certain functional literacy stage. Hence, the four language skills including listening, speaking, reading, and writing should be taught (Pusat kurikulum, 2006). The essential aspects to have adequate writing skill are vocabulary and grammar mastery (Soviyah, \& Etikaningsih, 2018). In this case, grammar itself needs to not only being memorized, but also comprehended by students (Haryudin, \& Argawati, 2018). Yet, in reality, Indonesian students often lost their interest to study English. They often get stuck on that language. Most of them blindly mix and blend the grammar into their sentences. They got language gap between Bahasa Indonesia and English. They had many differences including structure, grammar, terms, and styles (Soviyah, \& Etikaningsih, 2018). Consequently, students often get confused in writing activity. Yet, those obstacles can be overcome by engaging the appropriate strategy, method, or media (Manan, 2017). For example, Solihati (2016) suggested smart wheel as a choice to teach English tenses and Magic Round (Solihati, 2017, 2018). Yet, to teach affirmative sentence and negative sentence, different Magic Round will be used as Magic Round was developed in three series, including affirmative, negative, and interrogative sentence. The separation avoids users' confusion as experienced in the usage of Smart Wheel. The developed media had functions which are in line with the characteristics of teaching media. They are clarifying the message, overcoming the limitation of time, space, and energy, having more direction between student and teacher, enabling students to learn independently, and fulfilling five components in learning process; teacher, material, media, student, and learning goals (Daryanto, 2016).

Since the previous developed media had not touched interrogative sentence yet, thus the last series of verbal sentence needed to be designed. It 
is called Magic Round for Interrogative Sentence. The core of the content itself is the same. It was designed to teach simple sentence, verbal type, and interrogative form. Thus, the intended material would be the agreement between subject and predicate.

Table 1 presents the pattern that students should know to arrange good sentences with full consideration on tenses.

Table 1. Pattern and tenses for interrogative sentence

\begin{tabular}{ccccc}
\hline & Present & Past & Future & Past Future \\
\hline Simple & Do/does+S+ & Did+S+V1? & Will+S+V1? & Would+S+V1? \\
& V1? & & & \\
Continuous & Am/are/is+S+ & Was/were+S+ & Will+S+be+Ving? & Would+S+be+Ving? \\
& Ving? & V.ing? & & \\
Perfect & Have/has S+V3? & Had+S+V3? & Will+S+have+ V3? & Would+S+have+V3? \\
Perfect & Have/has+S+ & Had+S+been+ & Will+S+ & Would+S+ \\
Continuous & been+Ving? & Ving? & have+been+Ving? & have+been+Ving? \\
\hline
\end{tabular}

After using Magic Round Negative students will be able in comprehending 16 (sixteen) tenses; simple present tenses, simple past tense, simple future tense, simple past future tenses, present continuous tense, past continuous tense, future continuous tenses, past future continuous tense, present perfect tense, past perfect tense, future perfect tense, past future perfect tense, present perfect continuous tense, past perfect continuous tense, future perfect continuous tense, and past future perfect continuous tense.

\section{METHOD}

The research was conducted in SMA At-Tajdid Boarding School, Grade XI IPS, Tasikmalaya West-Java. The class consists of 21 students; 6 males and 15 females. The 6 (six) steps model of Research \& Development (R\&D) which was a combination of Borg \& Gall' and Dick \& Carey' are used in this research (Sugiyono, 2010). The modification of the model could be seen in Figure 1.

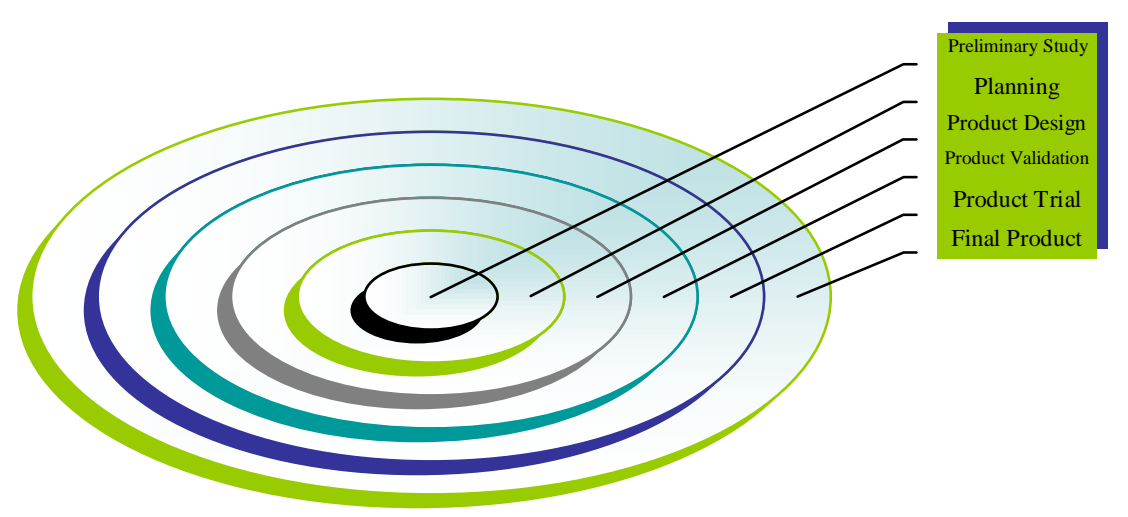

Figure 1. Research model

Preliminary study covered several activities, namely references finding, field observation, problem identification, and needs identification. They were the keys of digging up related information to the raised issue. Planning step included identifying general goal in learning process, analyzing learning process to develop the media, developing learning strategy, developing or selecting appropriate material, developing test instrument and product validation. Meanwhile, the product design concerns on creating and developing the media itself. It considers the material included, the design developed, the color used, the content provided, the font size applied, etc. Product validation was the next step to carry out. It would engage the assessment from the technology expert, material expert, and teacher as the user in delivering the material, observer, and students. After doing product validation, product trial should be assessed. It would consist of 3 (three) scales; individual scale, small scale, and limited scale. All the scales' assessment toward the developed media would decide the revision on the developing media. The feedback from doing product validation and its trial were the constructive suggestions for producing the final product. Table 2 shows the instruments used to 
gather data, especially for doing product validation.

Table 2. Instrument to get the accuracy of developing media

\begin{tabular}{|c|c|c|c|c|}
\hline The Function & $\begin{array}{c}\text { To assess the accuracy of } \\
\text { Magic Round }\end{array}$ & $\begin{array}{l}\text { To assess the } \\
\text { feasibility of } \\
\text { Magic Round }\end{array}$ & $\begin{array}{l}\text { To assess the } \\
\text { usefulness of } \\
\text { Magic Round }\end{array}$ & $\begin{array}{c}\text { To assess students' } \\
\text { achievement }\end{array}$ \\
\hline $\begin{array}{c}\text { The } \\
\text { Instrument }\end{array}$ & Questionnaire & $\begin{array}{l}\text { Teacher's } \\
\text { response }\end{array}$ & $\begin{array}{c}\text { Observation } \\
\text { sheet }\end{array}$ & Objective test \\
\hline $\begin{array}{c}\text { The } \\
\text { Respondent }\end{array}$ & $\begin{array}{l}\text { Technology } \\
\text { Expert }\end{array}$ & Teacher & Observer & Students \\
\hline The Amount & 23 items & 14 items & 24 items & 25 items \\
\hline
\end{tabular}

Except the instrument fulfilled by the students, the assessment would be evaluated by giving score 1-4. Each would indicate level of agreement, including strongly disagree, disagree, agree, and strongly agree. On the other hand, to measure the effectiveness of the media, multiple choices test was used. Both pre-test and post-test consist of 25 items with matching model. The students had to match the sentences on the left toward the tenses type on the right by putting the number and the letter. Product trial would spend 6 (six) meetings for each scale. The meeting consists of pre-test, present tenses mastery, past tense mastery, future tense mastery, past future tense mastery, and post-test. The obtained data will then be interpreted following the criteria proposed by Widoyoko (2012) as presented in Table 3.

Table 3. Data interpretation

\begin{tabular}{ccc}
\hline No. & Percentage & Description \\
\hline 1. & $86 \%-100 \%$ & Quiet valid and practical, can be used without revision \\
2. & $71 \%-85 \%$ & Valid and practical enough, can be used with a little revision \\
3. & $56 \%-70 \%$ & Less valid and practical, need much revision \\
4. & $41 \%-55 \%$ & Not valid and practical, cannot be used \\
5. & $26 \%-40 \%$ & Not valid at all, cannot be used \\
\hline
\end{tabular}

\section{RESULTS AND DISCUSSION Product validation}

Magic Round Interrogative was the third series of the whole Magic Round for learning verbal active sentences. It was developed the same as the previous media. Corel Draw Application was implemented during the development of the media. Magic Round interrogative had a very little different from the negative series. Those were from the colour, the sentence pattern, and the examples of the sentence. Magic Round had 4 (four) layers; the first described the types of tense and the pattern, the second and the third displayed the 99 irregular verbs, and the forth provided the explanation and the examples. Using Magic Round was easy. Just spin the layer 1 to get the verb that the user wanted. If they did not understand the meaning, the outer part had provided the meaning in Bahasa Indonesia. The verbs were arranged alphabetically. If the verbs could not find in the $2^{\text {nd }}$ layer, handle it together with the $1^{\text {st }}$ to see the verbs in layer 3 . Magic Round itself had 99 irregular verbs which were separated in 49 and 50. The backside of the media provided the function or explanation of the English tenses. The users could easily get their comprehension toward various tenses. Then they would use the tense appropriately as their needs and meaning. The explanation itself was also completed by examples. Thus, the users could check their own writing or sentence arrangement. For the visual description, Magic Round could be seen in Figure 2. 
Tri Agustini Solihati \& Lystiana Nurhayat Hakim

Developing magic round to teach interrogative sentences

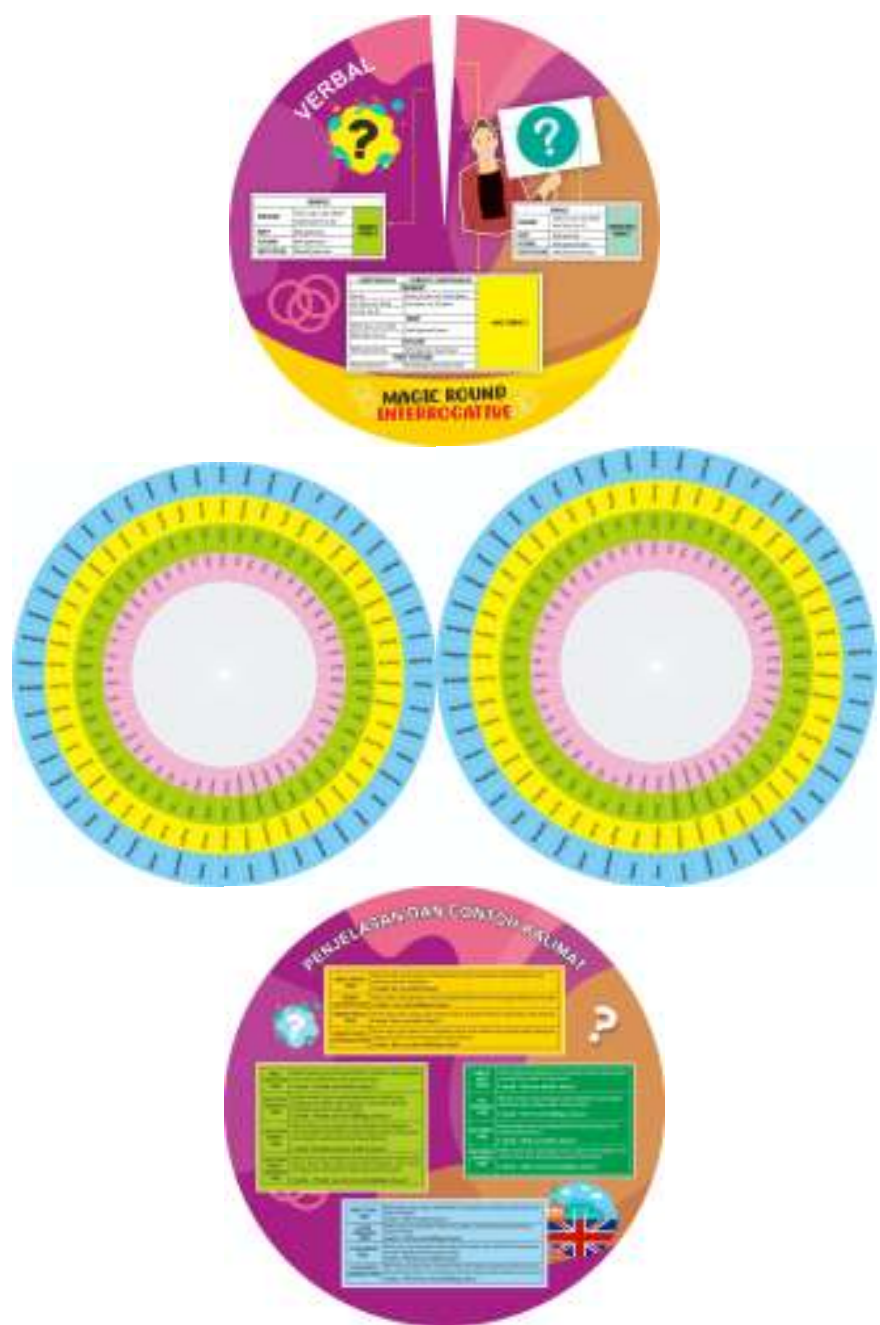

Figure 2. Four-sided Magic Round

Magic Round as seen above had already been validated by the experts. Those were technology expert and material expert. Validation itself was done in three scales. First, the experts gave their assessment toward the developed media through
23 items of questionnaire. The level of agreement over each statement should be between score 1-4. The given score was converted into percentage and categorized as seen in Table 4.

Table 4. Experts validation

\begin{tabular}{cccccccc}
\hline \multirow{2}{*}{ The Experts } & \multirow{2}{*}{ Validation Scale } & \multicolumn{4}{c}{ Score } & \multirow{2}{*}{ Converted } & \multirow{2}{*}{ Conclusion } \\
\cline { 3 - 6 } Technology Expert & $\mathbf{1}$ & $\mathbf{2}$ & $\mathbf{3}$ & $\mathbf{4}$ & score & \\
& Individual & - & - & 14 & 9 & 85 & Quiet valid \\
& Small & - & - & 12 & 11 & 87 & and practical, \\
& Limited & - & - & 10 & 13 & 90 & can be used \\
\multirow{3}{*}{ Material Expert } & Individual & - & - & 14 & 9 & 85 & without \\
& Small & - & - & 11 & 12 & 88 & revision \\
& Limited & - & - & 7 & 16 & 92 & \\
\hline
\end{tabular}




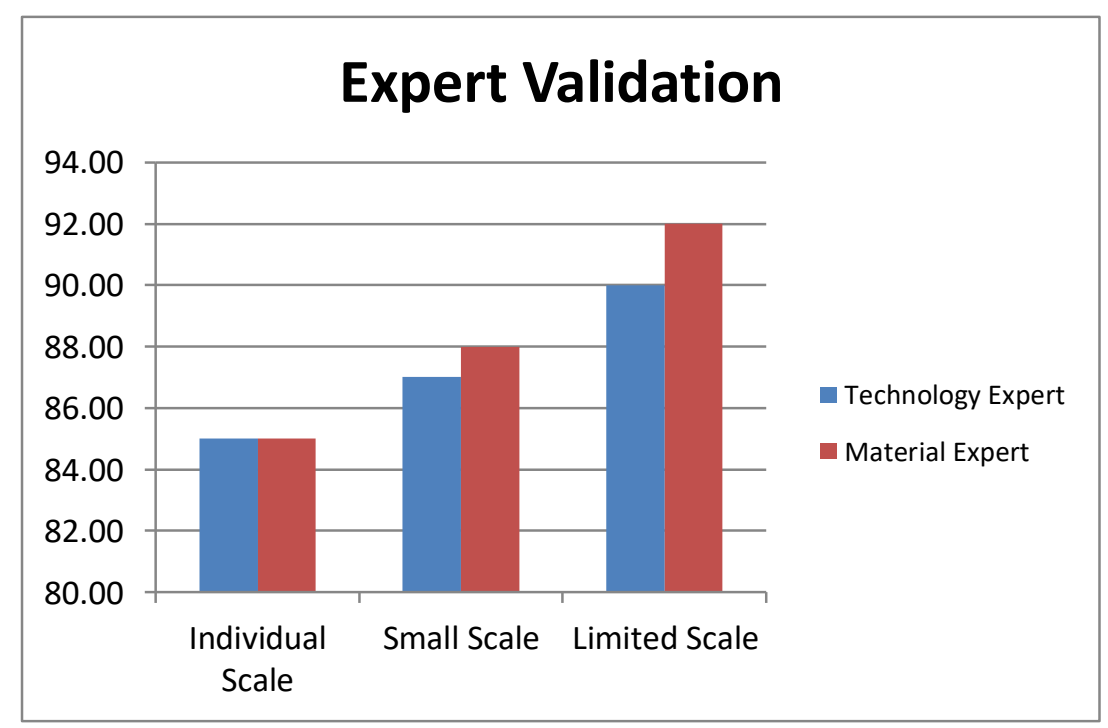

Figure 3. The result of expert validation

By observing the data, Magic Round was quiet valid and practical and can be used without revision. It was determined from data interpretation in Table 3. The result ranging from the top 2 category was gained. Both technology expert and material expert gave the same score in individual scale which was 85 . It reflects that the media was valid and practical enough. It could be used with a little revision. Little revision suggested by them was about the following topics; colour and picture. At the beginning of the steps, Magic Round was printed in uninteresting colour. Actually, it was an error from the ink of the printing machine and also from the resolution of the design. There was a change of resolution from the previous developed Magic Round. Then, the second point was about the picture which modified the media. It was not good in the first because many pictures often distracted students' attention. They would be more attracted to the given pictures instead of the material inside. The picture was successfully simplified and already represented the content of the developing material.

Otherwise, the result of product validation was very great in both small scale and limited scale. It was absolutely because of the suggestions in the individual scale were done very well. No more notes and suggestions, instead of conveying high appreciation toward the media.
The given results in small scale were 87 and 88 . Besides, in limited scale, the results from technology expert reached 90 compared to material expert which was 92. The entire result was determined as valid and could be used without revision. One thing that experts said was about the existence of the media. The previous similar media had already developed and been accepted by students and teacher very well.

\section{Product Trial}

Product trial was done in 3 (three) scales as well as the product validation. It was divided into individual scale, small scale, and limited scale. For the first two, the students were chosen based on teacher's suggestion to have high, medium, and low cognitive level. Yet, the last would have the rest of two scales. All activities for each were the same. It consists of the assessment from the teacher as the user of Magic Round to measure the feasibility, the observer to measure the usefulness of Magic Round, and students' achievement test to measure their comprehension toward the material learnt (interrogative sentences).

Feasibility questionnaire consists of 14 items, usefulness questionnaire has 24 items, and achievement test has 25 items. The summary result of product trial in all stages is shown in Table 5.

Table 5. Product Trial

\begin{tabular}{ccccccc}
\hline \multirow{2}{*}{ The assessment } & \multirow{2}{*}{ Validation Scale } & \multicolumn{4}{c}{ Score } & Converted \\
\cline { 3 - 6 } & & $\mathbf{1}$ & $\mathbf{2}$ & $\mathbf{3}$ & $\mathbf{4}$ & score \\
\hline \multirow{3}{*}{ Feasibility } & Individual & - & - & 8 & 6 & 86 \\
& Small & - & - & 7 & 7 & 88 \\
& Limited & - & - & 5 & 9 & 91
\end{tabular}


Tri Agustini Solihati \& Lystiana Nurhayat Hakim

Developing magic round to teach interrogative sentences

\begin{tabular}{ccccccc} 
& Individual & - & - & 16 & 8 & 83 \\
Usefulness & Small & - & - & 14 & 10 & 85 \\
& Limited & - & - & 10 & 14 & 91 \\
\hline
\end{tabular}

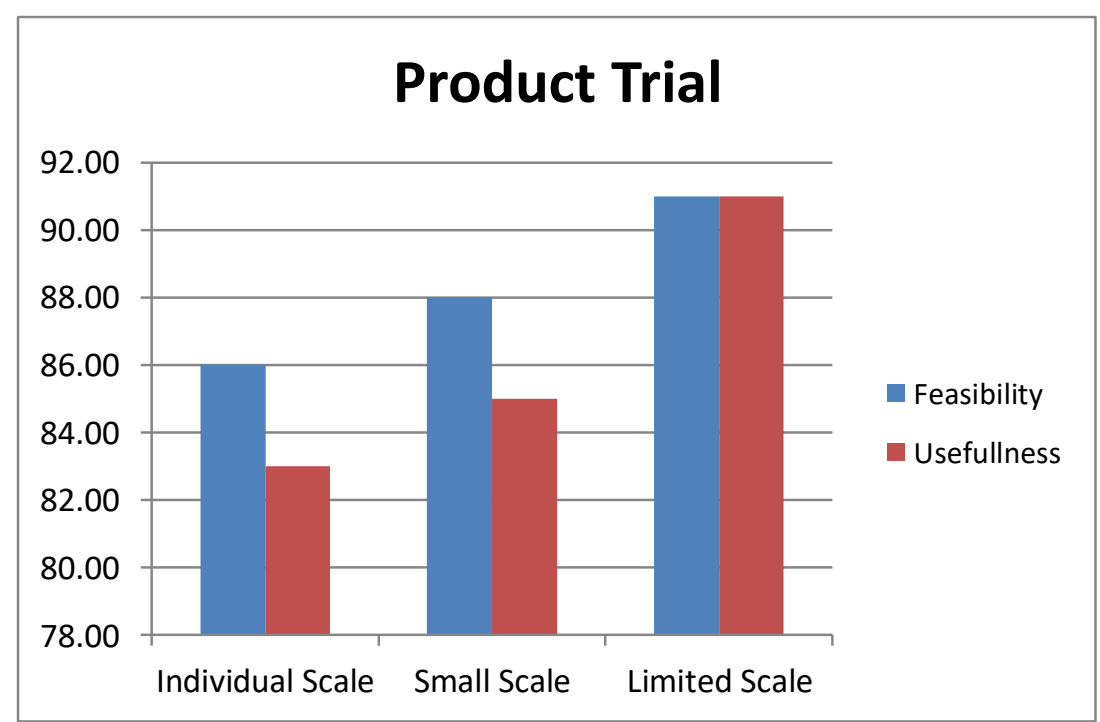

Figure 4. Usefulness and feasibility of Magic Round

From the data presented in Table 5, the feasibility of Magic Round interrogative had been assessed as valid and practical media. It could be used without revision. The data was gained from the observer. The observer proposed 14 statements to be assessed. It covered the overall performance of the teacher (the user of Magic Round in the classroom) relating to the media in the classroom activities. In the individual scale, 8 items got point 3 and 6 items got point 4 . It bridged the result of 86 . Meanwhile, in small scale, point 3 and 4 had the same amount of the item. It was 7 items for each. It resulted 88 . The last scale or limited scale, 5 items got point 3 , and 9 items got point 4 . The evaluated items were presented in Table 7.

Table 7. Questionnaire of feasibility of Magic Round

\begin{tabular}{|c|c|}
\hline Number of item & The statements \\
\hline 1 & Teacher opens the class by greeting, praying, and checking students' attendance. \\
\hline 2 & Teacher does an apperception to invite students in digging up what to learn that day. \\
\hline 3 & Teacher states the learning competency. \\
\hline 4 & Teacher informs the students on what activities will be done during the class. \\
\hline 5 & Teacher connects the benefits of today lesson toward daily life. \\
\hline 6 & The media engages students' activities. \\
\hline 7 & The media is appropriate to use to reach learning objectives. \\
\hline 8 & The media assists students to find a concept that relates to the learning objectives. \\
\hline 9 & $\begin{array}{l}\text { The media facilitates the students in comprehending the material toward a set of activity } \\
\text { inside. }\end{array}$ \\
\hline 10 & The media bridges students to have easy and fun learning. \\
\hline 11 & The media supports the students to have joyful learning experience. \\
\hline 12 & $\begin{array}{l}\text { The media is possibly designed to help students in observing, asking, collecting, } \\
\text { analyzing data, and drawing conclusion. }\end{array}$ \\
\hline 13 & Teacher supports the students to state their learning impression. \\
\hline 14 & $\begin{array}{l}\text { Teacher invites the students to write down some constructive suggestions as a reference } \\
\text { to a better learning process later. }\end{array}$ \\
\hline
\end{tabular}

Moreover, in assessing the usefulness of Magic Round Interrogative, the score in individual scale and small scale indicated that the media needed a little revision. 16 items got point 3 and 8 items got point 4 . It results 83 in individual scale. 14 items got point 3 and 10 items got point 4 . It brought the result of 85 in small scale. It was because the language that teacher used sometimes was hard to understand. Teacher needed to blend Bahasa Indonesia and 
English, and talk a bit slowly. Yet, in the limited scale, it can be concluded that the media was practical and could be used without revision. The result was 91 with 10 items got point 3 and 14 items got point 4 . Table 8 presents the statement to be assessed.

Table 8. Questionnaire of measuring the usefulness of Magic Round

\begin{tabular}{cl}
\hline Number of item & The statements \\
\hline 1 & Learning activity is more fun by the developing teaching media. \\
3 & The material within the media is easy to understand by the teacher. \\
4 & Teacher is able to create creative learning activity by the usage of the developing media. \\
5 & Teacher is able to discuss with the students using the media. \\
6 & The material is very helpful for students to reach the learning objectives. \\
7 & The examples of the explanation are suitable to learning objectives which must be \\
8 & reached by the students. \\
9 & The material is suitable with the students' growth level. \\
10 & The language is communicative while being used in explaining the material/ learning \\
& activity \\
11 & Using the developing media in learning activity has engaged students actively in \\
12 & constructing or creating their own knowledge. \\
13 & Students' learning activity is better than the previous similar material without using \\
14 & Students' activity is more active, creative, and fun. \\
15 & The developing media motivates students to study harder by using it. \\
16 & Students are motivated and have more spirit to study. \\
17 & The media is helpful to easily understand the material. \\
18 & The media is valuable to assist students' indoor and outdoor activity. \\
19 & The media's font size is readable. \\
20 & The media's font face is interesting. \\
21 & The appropriateness of media's layout is attractive. \\
22 & The appropriateness of media's layout does not distract students' attention. \\
23 & The illustrated picture is suitable toward the developing media. \\
24 & The color of media does not disturb students' concentration. \\
& The media is easy to use. \\
& The media is practical to use by the students.
\end{tabular}

After being analysed in the preliminary study, (passing grade) to measure the students' looking at the students learning experience and understanding and achievement. Table 9 shows discussing with the teacher, the researcher the result of students' achievement test. decided score 68 as the minimum standard

Table 9. Students' achievement result in individual scale

\begin{tabular}{cccccc}
\hline No. & Name & Correct Answer & Pre-Test Score & Correct Answer & Post-Test Score \\
\hline 1. & R-1 & 9 & 36 & 18 & 72 \\
2. & R-2 & 9 & 36 & 17 & 68 \\
3. & R-3 & 12 & 48 & 20 & 80 \\
Average & 10 & 40 & 18 & 73 \\
\hline
\end{tabular}

From the table, the comparison between the result of pre-test and post-test showed a good progress. All respondents could improve their understanding by passing the minimum score as the passing grade which was 68 . They were given 25 matching test. Respondent 2 got only a minimum passing grade, but the overall average reached 73. It was about the minimum score that determined the success of Magic Round to improve their understanding.
In the middle of having pre-test and post-test, they had a set of meeting to especially focus on the usage of Magic Round in learning interrogative sentence. They stated in the end of the meeting that Magic Round was very interesting to use, easy to understand the material, and covered all material about interrogative sentence. Patterns, examples, explanation, and irregular verbs were provided completely in a teaching media. It was their first time seeing and using Magic Round to master English tenses. 
Tri Agustini Solihati \& Lystiana Nurhayat Hakim

Developing magic round to teach interrogative sentences

Table 10. Students' achievement result in small scale

\begin{tabular}{cccccc}
\hline No. & Name & Correct Answer & Pre-Test Score & Correct Answer & Post-Test Score \\
\hline 1. & R-1 & 7 & 28 & 16 & 64 \\
2. & R-2 & 9 & 36 & 18 & 72 \\
3. & R-3 & 8 & 32 & 17 & 68 \\
4. & R-4 & 13 & 52 & 20 & 80 \\
5. & R-5 & 10 & 40 & 18 & 72 \\
6. & R-6 & 17 & 68 & 22 & 88 \\
\multicolumn{2}{l}{ Average } & 11 & 43 & 19 & 74 \\
\hline
\end{tabular}

Table 10 shows the result of students' achievement on the usage of Magic Round to master interrogative sentence. It consisted of 6 respondents. Respondent 1 was the only one who got the post-test score below the minimum grade. After being interviewed, the cause was healthy condition that decreased concentration. The amount of the test was the same as the previous scale which was 25 items of matching test. The overall average for the small scale reached 74 and it was absolutely above the determined grade.

The students highly appreciated the Magic Round. They considered this as innovative media, because the complex material was easy to understand by using it. It was very helpful and able to increase their learning motivation.

Table 11. Students' achievement result in limited scale

\begin{tabular}{cccccc}
\hline No. & Name & Correct Answer & Pre-Test Score & Correct Answer & Post-Test Score \\
\hline 1. & R-1 & 12 & 48 & 18 & 72 \\
2. & R-2 & 11 & 44 & 23 & 92 \\
3. & R-3 & 12 & 48 & 22 & 88 \\
4. & R-4 & 10 & 40 & 20 & 80 \\
5. & R-5 & 10 & 40 & 23 & 92 \\
6. & R-6 & 9 & 36 & 18 & 72 \\
7. & R-7 & 12 & 48 & 25 & 100 \\
8. & R-8 & 11 & 44 & 22 & 88 \\
9. & R-9 & 12 & 48 & 18 & 72 \\
10. & R-10 & 15 & 60 & 25 & 100 \\
11. & R-11 & 10 & 40 & 17 & 68 \\
12. & R-12 & 10 & 40 & 17 & 68 \\
\multicolumn{7}{c}{ Average } & 11 & 45 & 21 & 83 \\
\hline
\end{tabular}

The last scale of product trial was limited scale. It was followed by the rest students from the individual and small scale. Thus, the amount of respondent was 12 students. Two of them had the same post-test score as the minimum passing grade. The other two got perfect score or 100 . Both of them were able to answer all the tests correctly. The rest scores itself were varied. Yet, it brought this scale to get the average of 83 which was the highest among the scales. It showed that students' achievements and understanding were good, because it was above the minimum passing grade.
The students stated that learning activity was very interesting. Magic Round was very helpful. It facilitated the students to understand the English tenses, especially in the form of interrogative sentence. They had been aware to combine grammar blindly and just put the question mark at the end of sentence to differ interrogative sentence to others. Magic Round was developed completely, including tenses names, their patterns, their explanation, their examples, and irregular verbs to use. Figure 5 describes the comparison of students' average scores in all stages. 


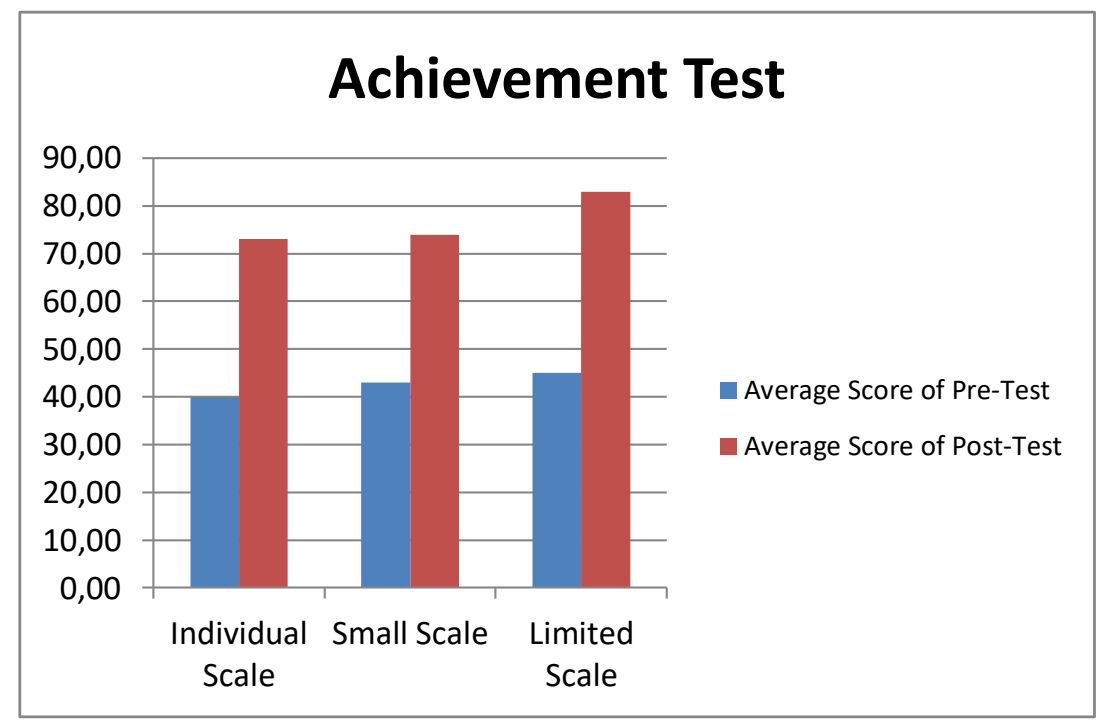

Figure 5. Average score of achievement test

How to use Magic Round in teaching process First of all, teacher needs to dig up students' knowledge toward kinds of English tenses by mentioning their names. Then, they have to create some sentences related to English tenses they mentioned. They can also make a little discussion with their classmates to develop their understanding. The common mistakes of making interrogative sentences were; 1) changing only the intonation while producing interrogative sentence; 2) adding only the question mark at the end of the sentence; 3) Using only simple form (V1) in all kinds of English tense. Students blindly mix the structure as they feel as true; 4) being confused to have subject and verb agreement and other parts of speech; and 5) having lack of knowledge about the function or the usage of each English tense. It made inappropriate use of tense toward the intended message to tell.

To minimize these mistakes, teachers need to make students aware of English tenses by knowing their names. Thus, the second thing a teacher could do was emphasizing the students to remember the abbreviation of "SeCoPerPeci". That word was very familiar for Indonesian people. "Se" would be used forever to indicate "Simple", "Co" would indicate "Continuous". "Per" would show "Perfect", and "Peci" would describe "Perfect Continuous". Furthermore, to get 16 (sixteen) tenses, SeCoPerPeci needed to be combined to main terms. Those were present, past, future, and past future. After being able to mention fluently and memorize the name perfectly, teacher could start explaining the function of each tense which was provided in the back side of Magic Round. Then, teachers ask the students to analyse the difference sentence structure from the example, go back to the front side of Magic Round to see the pattern and subject-verb agreement, and then make some sentences using different verbs and tenses. Those teaching arrangement could be repeated the same or better using another teaching approach, strategy, model, or method.

\section{CONCLUSION}

In short, after being assessed through some evaluation that engaged different participants, Magic Round was appropriate to be used in teaching interrogative sentence. It can improve students' mastery of interrogative sentence. They could easily know the pattern of the sentence, memorize and enrich their vocabulary both English and Bahasa Indonesia, comprehend the usage of each tense from the explanation, and match their comprehension with the sentence example. Magic Round was suitable to use for the beginners. Thus, everyone that is interested in English, especially for the sentence structure mastery could bring Magic Round along their study. Magic Round was designed to be used both individually and group work. As long as they knew the way to use it, self-study was very possible to do. Teachers also could provide fun learning by attending or engaging teaching media on their classroom activities. To sum up, Magic Round for teaching interrogative sentence was valid and practical. 


\section{ACKNOWLEDGEMENTS}

I would like to express our highest gratitude to SMA AT-Tajdid Tasikmalaya where this research was carried out, especially for English teacher and students of XI-IPS, the technology and material experts, the dean of Faculty of Education and Teacher Training, and all of the lecturers in Universitas Perjuangan Tasikmalaya. The last, I thank to DRPM Kemenristekdikti which supported this research.

\section{REFERENCES}

Daryanto. (2016). Media pembelajaran. Yogyakarta: Gava Media.

Haryudin, A., \& Argawati, N. O. (2018). Lesson study to improve student English grammar mastery using jigsaw technique to the third semester of IKIP Siliwangi. Indonesia EFL Journal, 4(1), 4956. doi: 10.25134/ieflj.v4i1.798.

Manan, N. A. (2017) Whatsapp mobile tool in second language learning. Indonesia EFL Journal, 3(1), 87-92

Pusat Kurikulum (Puskur). (2006). Standar isi bahasa Inggris (Content standard for English). Jakarta.
Solihati, T. A. (2016). The effect of using smart wheel toward the skill of arranging simple sentences (Pengaruh penggunaan smart wheel terhadap keterampilan menyusun kalimat sederhana. Jurnal Saung Guru, IX(3).

Solihati, T. A. (2017). Pengembangan Magic Round pada pembelajaran tenses untuk penyusunan kalimat affirmative. Tasikmalaya: Universitas Perjuangan.

Solihati, T. A., \& Aristi, G. (2018). Akselerasi pemahaman tenses dalam menyusun kalimat negative dengan Magic Round. Jurnal Sosial \& Humaniora IKRA-ITH Humaniora, 2(3), 126132.

Soviyah, S., \& Etikaningsih, D. R. (2018). Instagram use to enhance ability in writing descriptive texts. Indonesian EFL Journal, 4(2), 32-38. doi: 10.25134/ieflj.v4i2.1373.

Sugiyono. (2010). Metode penelitian pendidikan pendekatan kuantitatif, kualitatif, dan $R \& D$. Bandung: Alfabeta.

Widoyoko, S. E. P. (2012). Teknik penyusunan instrumen penelitian. Yogyakarta: Pustaka Pelajar. 